Edição especial - Sociedade e ambiente no Semiárido: controvérsias e abordagens

Vol. 55, p. 644-672, dez. 2020. DOI: 10.5380/dma.v55i0.73354. e-ISSN 2176-9109

SISTEMA
ELETROANICO
DE REVISTAS
SER I UfPR

\title{
Climate resilience building in Semi-Arid Lands (SALs): institutional weaknesses and strengths in subnational governments in Brazil
}

\section{Construção de resiliência climática em Territórios Semiáridos (TSAs): fraquezas e fortalezas institucionais de governos subnacionais no Brasil}

\author{
Carlos Germano Ferreira COSTA ${ }^{1 *}$ \\ ${ }^{1}$ Ministry of Science, Technology, Innovation and Communications, Interministerial Commission on Global Climate Change, Brasília, DF, Brazil. \\ *E-mail para contato: carloscostainspira@gmail.com
}

Artigo recebido em 30 de abril de 2020, versão final aceita em 04 de setembro de 2020, publicado em 18 de dezembro de 2020

ABSTRACT: Well established institutions are an essential factor for the successful realization of sustainable socio-economic and environmental potential in Semi-Arid Lands (SALs). SALs receive limited attention in international climate research and policies; thus, the institutional relationship between governance, policy, and implementation continues to suffer from inconsistencies across governance levels. This research carried out an analysis combining mixed-research methods to collect, record, and analyze data and information regarding institutional and organizational strengths, weaknesses, opportunities, and threats, and local level policy implementation challenges and scope to assess the effectiveness of Disaster Risk Management (DRM) and implementation of adaptation policies at State and local levels in SALs. The inefficiencies observed in the DRM/CCA adaptation processes are concentrated in areas of high governance of state and municipal governments and stem from local communities' reduced organizational and technical capacity. It results in the negligent application of measures and resources to address climate risks. Therefore, this paper contributes to the increasing understanding of the institutional framework's role in the facilitation of local adaptation, revealing what seems to be working well, what is not, how things could improve in Brazilian SALs.

Keywords: climate adaptation; caatinga; AS/NZS ISO 31000; institutions; government-citizen interface; topdown; bottom-up; case studies. 
RESUMO: Instituições bem estabelecidas são um fator essencial para a realização bem-sucedida de potencial socioeconômico e ambiental sustentável em Terras Semiáridas (TSAs). TSAs recebem atenção limitada nas políticas e pesquisas internacionais sobre clima; dessa forma, o relacionamento institucional entre governança, política e implementação continua sofrendo inconsistências nos níveis de governança. Esta pesquisa realizou uma análise combinando métodos de pesquisa mista para coletar, registrar e analisar dados e informações sobre os pontos fortes, fraquezas, oportunidades e ameaças, desafios e oportunidades institucionais e organizacionais para avaliar a eficácia da Gestão de Risco de Desastres (GRD) e implementação de políticas de adaptação nos níveis estadual e local em TSAs. As ineficiências dos processos de GRD/adaptação observados concentraram-se em áreas de alta governança dos governos estaduais e municipais. Nesse sentido, a capacidade organizacional e técnica reduzida das comunidades locais resulta, na maioria dos casos, na aplicação negligente de medidas e recursos para lidar com os riscos climáticos. Dessa forma, esse artigo contribui para a compreensão crescente do papel do arcabouço institucional na facilitação da adaptação local, revelando o que parece estar funcionando bem, o que não está, e como políticas poderiam ser melhor implementadas em TSAs brasileiras.

Palavras-chave: adaptação ao clima; caatinga, AS/NZS ISO 31000; instituições; interface governo-cidadão; top-down; bottom-up; estudos de caso.

\section{Introduction}

Semi-Arid Lands (SALs) in developing and emerging countries are high-risk climate change hotspots, and of all subtypes of global drylands, Semi-Arid zones have the most significant area, which accounts for more than one-third of the total dryland area (UNCCD, 2011; De Souza et al., 2015; Tucker et al., 2015; Huang et al., 2015). Globally, SALs are home to roughly one billion people, especially some of the poorest and least food secure populations (Gannon et al., 2020). Additionally, two billion people live in the so-called drylands, which cover about $41 \%$ of the terrestrial land surface and produce $44 \%$ of the crops, and half of the world's livestock (UNCCD, 2011). In Latin America and the Caribbean (LAC), about one-fourth of the territory is desert ${ }^{1}$ and drylands ${ }^{2}\left(20,533,000 \mathrm{~km}^{2}\right)$. In northeastern Brazil, Semi-Arid Lands, and tropical savannahs dominate the landscape (UNCCD, 2020). The Caatinga biome, found in Brazil's northeastern region, is the most populated Semi-Arid Land on the planet and remarkably vulnerable to land degradation due to climatological and anthropogenic factors (Santos et al., 2020). The Northeast region of Brazil is among the hardest hit by the immediate repercussions of climate change as global warming trends are foreseen to be expressly intense in these ecosystems, with droughts and floods already becoming more severe (IPCC, 2014; Marengo et al., 2018).

In this biome, as in other SALs of the world, the expanding incidence and significance of severe

\footnotetext{
1 The deserts of the Pacific coast range from southern Ecuador beyond the entire Peruvian shoreline to northern Chile. Further inland, at altitudes of 3,000-4,500 meters, the high plains, or Altiplano, of the Andean mountains cover large areas of Peru, Bolivia, Chile, and Argentina (UNCCD, 2020).

${ }^{2}$ To the East of the Andes, an arid region extends from Chaco's northern reaches in Paraguay to Patagonia in southern Argentina (UNCCD, 2020).
} 
hydrometeorological events pose potentially disastrous consequences for agriculture and food security, making vulnerable populations further exposed to climate and environmental variability (Hatfield $e t$ al., 2018). The Semi-Arid region of Northeast Brazil (NEB) usually experiences severe droughts during "El Niño Southern Oscillation" (ENSO) years, with significant impacts on the dynamics of the native vegetation (Caatinga), society and economy (Ting et al., 2009; Marengo et al., 2018; Pereira et al., 2020). Furthermore, Semi-Arid Lands have expanded expressively over the last 61 years at different paces and patterns globally, due to factors ranging from drying or wetting trends -dominated by long-term global sea surface temperature (SST) anomalies, or by local land surface processes due to human activities, and anthropomorphic global warming (Kane, 2009; Ting et al., 2009; Huang et al., 2015; Rajaud \& Noblet-Ducoudré, 2017; Marengo et al., 2018). Droughts are natural disasters, and their occurrence compromises water and energy security and subsistence agriculture in regions such as NEB (Marengo et al., 2018). Nonetheless, SALs, especially in Brazil, still receive little or limited attention in international climate policy and research, suffering remarkable insufficiencies concerning proactive disaster preparedness and prevention at the national and local levels ${ }^{3}$ (CSNA; 2014; Huang et al., 2015; WMO/GWP, 2017; Gannon et al., 2020).

Disaster Risk Management involves a set of methodologically structured procedures in the face of adversities in a planned, institutionalized and systemic way. In general, Risk Management adds value to processes by generalizing its practices (Wisner et al., 2020), and promoting changes in behavior (Davis et al., 2015); so that there can be an institutional and organizational improvement in these conditions (UNDRR, 2020). Notwithstanding, a less than optimal level of participation of stakeholders at the national level, combined to insufficient socio-economic conditions, seem to undermine the adequacy of DRR policies to the local reality and may compromise the implementation of sectoral plans, combined with the tensions and the gaps between climate adaptation policies on the one hand, and their adequacy and implementation on the other (Alves et al., 2020).

In this paper, we argue that well-established institutions are essential for the successful realization of the sustainable socio-economic and environmental potential of SALs, the protection of human life and the environment, and the reduction of unsustained human migratory patterns (Mensah, 2019). The relationship between governance, policy, and implementation is complicated, and the inconsistencies across levels of governance highlight the need for a versatile approach to elucidate top-down policy development and bottom-up implementation challenges in long-term cross-sectoral planning (England et al., 2018; Ranabhat et al., 2018; Williams et al., 2020). In this regard, it is unavoidable to recognize how structured government risk-taking approaches guide patterns of behavior, to propose changes with solid reasoning

\footnotetext{
${ }^{3}$ Huang et al., (2015) investigate regional climate changes in Semi-Arid Lands globally -1990-2004 relative to 1948-1962 period-, for eight selected SALs worldwide, i.e., East Asia, Central Asia, northern Africa, North America, South America (leeward of the Andes Mountains), southern Africa, central/west Australia, and east Australia. However, the study does not include the Caatinga in Northeast of Brazil.
} 
(Davis et al., 2015). With this in mind, this research carried out an analysis of the existing Disaster Risk Management (DRM) baseline in Brazil, and in the State of Ceará and its support lines provided by the various development and government agencies aimed at improving the understanding of the causes of institutional and organizational weaknesses and strengths in climate-related Disaster Risk Reduction (DRR) in SALs. The present investigation attempts to provide new insight on institutional approaches for climate-related DRM in the State of Ceará. This discussion could benefit other SALs, by contributing to the formulation and adjustment of proposals capable of improving public institutions and processes, tools, and instruments for identifying, planning, and responding to adaptation challenges.

\section{Methodology}

\subsection{Study Area}

The State of Ceará is in Brazil's Northeast region, bordering the Atlantic Ocean in the North. It has 573 kilometers of coastline; to the South, it borders the State of Pernambuco; to the East, the states of Rio Grande do Norte and Paraíba; and, to the West, the State of Piauí. It has a total area of $148,886.308 \mathrm{~km}^{2}$ (Figure 1).

The Brazilian semi-arid region is the largest SAL globally and has an area of $982,566 \mathrm{~km}^{2}$, which corresponds to $18.2 \%$ of the national territory, $53 \%$ of the Northeast region. The Semi-Arid population is about 22 million inhabitants, and it includes the

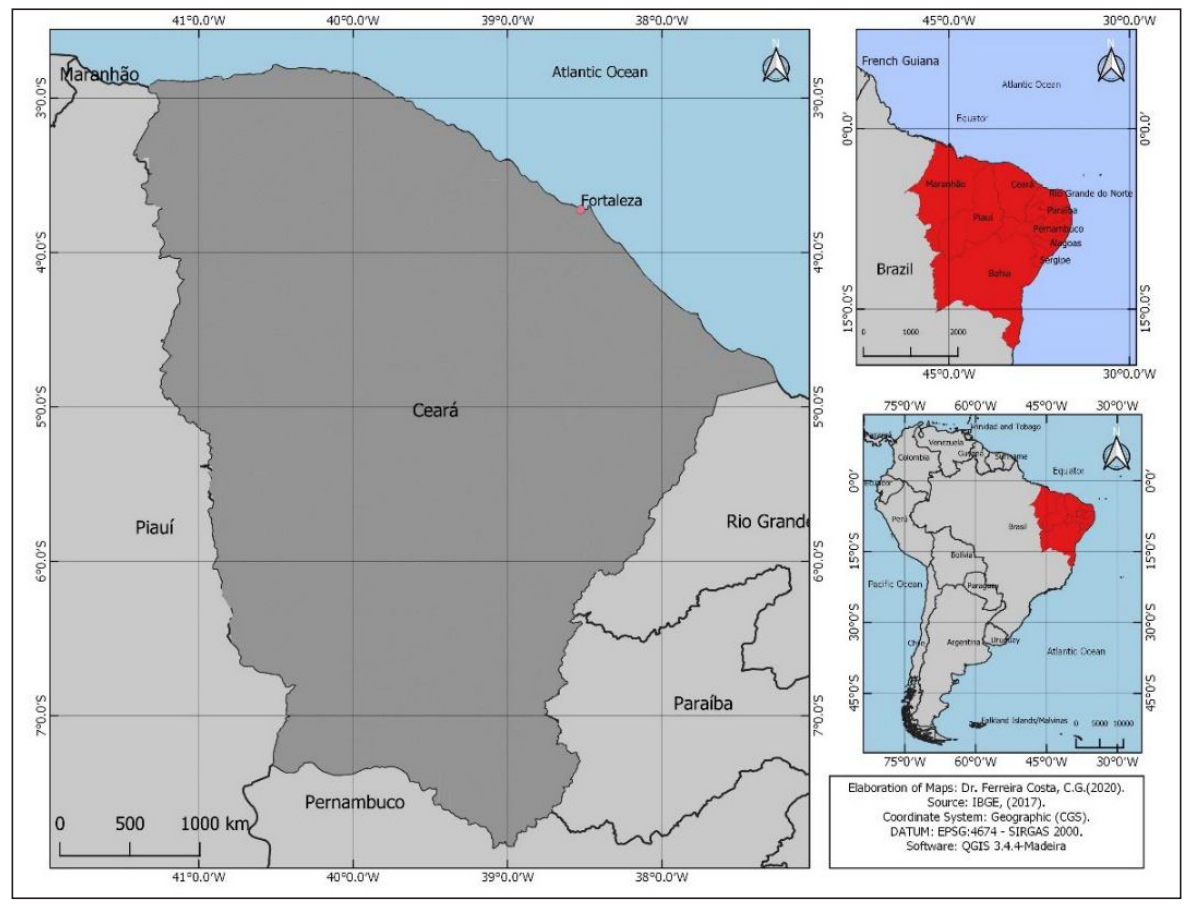

FIGURE 1 - Location of the State of Ceará.

SOURCE: Maps Elaborated by the Authors of this Research; IBGE, 2017; QGIS 3.4.4-Madeira. 
largest concentration of rural population in Brazil (CSNA, 2014). Technical and scientific criteria fundaments the delimitation of the Semi-Arid Land in the Northeast as follows: (i) average annual rainfall of $800 \mathrm{~mm}$ or less; (ii) thorntwaite Aridity Index equal to or less than 0.50; and; (iii) daily percentage of water deficit equal to or greater than $60 \%$, considering every day of the year; which initially included 1.189 municipalities in the Brazilian SAL (SUDENE, 2017a). However, manifestations from the Ministry of National Integration (MI) and SUDENE, through the Semi-Arid WG Report -consolidating the analysis of appeals filed by some states in the requested review of the list of municipalities -, resulted in additional 73 municipalities integrated to the list. Currently, Brazilians SALs counts 1,262 municipalities (SUDENE, 2017b; 2020).

\subsection{Study Sites}

We based the selection of municipalities on official data from the Federal Government and Civil Defense register of disaster events in the State of Ceará in the last 20 years (MDR, 2012). We crossed

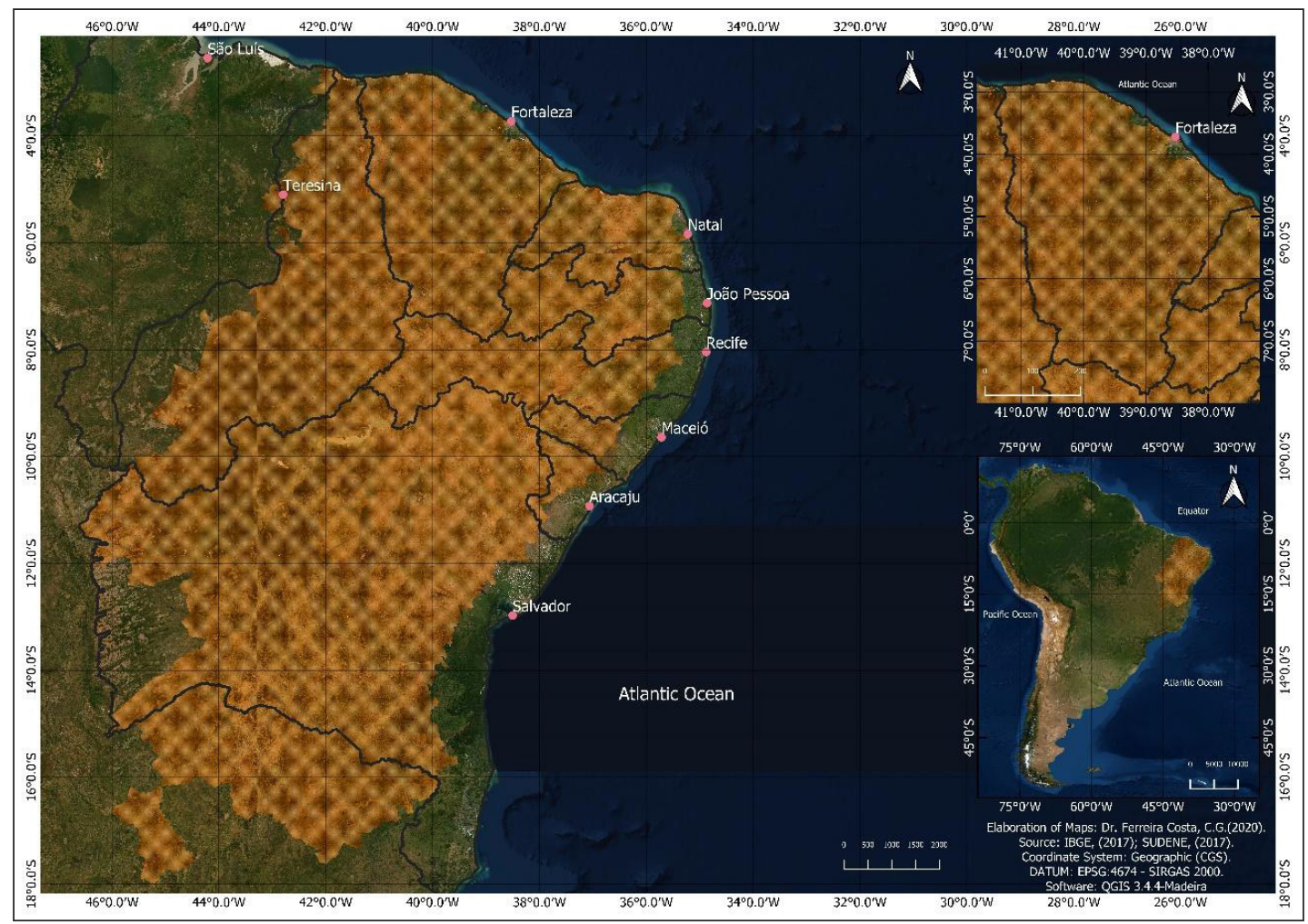

FIGURE 2 - Delimitation of Semi-arid lands (SALs) - Caatinga - in the Northeast Portion of the South American Continent, with the State of Ceará, and the Northeast Region in Evidence.

SOURCE: Maps Elaborated by the Authors of this Research. IBGE, 2017; SUDENE, 2017; 2020; QGIS 3.4.4-Madeira. 
these registers with statistical data regarding population, socio-economic/institutional factors, and geographic delimitation of the territory. For this stage of the work, we selected six municipalities in the State of Ceará, according to the frequency of adverse hydrometeorological events - explicitly related to droughts, floods, and forest fires. The sampling of municipalities for field research was accompanied by a previous geographic stratification that considered the variables and analyzed both for population-based disasters, institutional capacity, among the Ceará's State Rural Development Territories (IPECE, 2020).
In this context, in the 14 Territorial Planning Regions, six municipalities were selected to represent distinct patterns or "types" of geographic and institutional dynamics in Disaster Risk Management of the most considerable interest for the present study ${ }^{4}$. We carried out field visits to the Municipalities of Quixadá (87,728 inhabitants), São Gonçalo do Amarante (48,422 inhabitants), Piquet Carneiro (16,969 inhabitants), Aracati (74,547 inhabitants), Crateús (75,074 inhabitants), and Fortaleza $(2,669,342$ inhabitants), totalizing six field visit sites (IBGE, 2019) (Figure 3). The selected municipalities' location is in what is con-

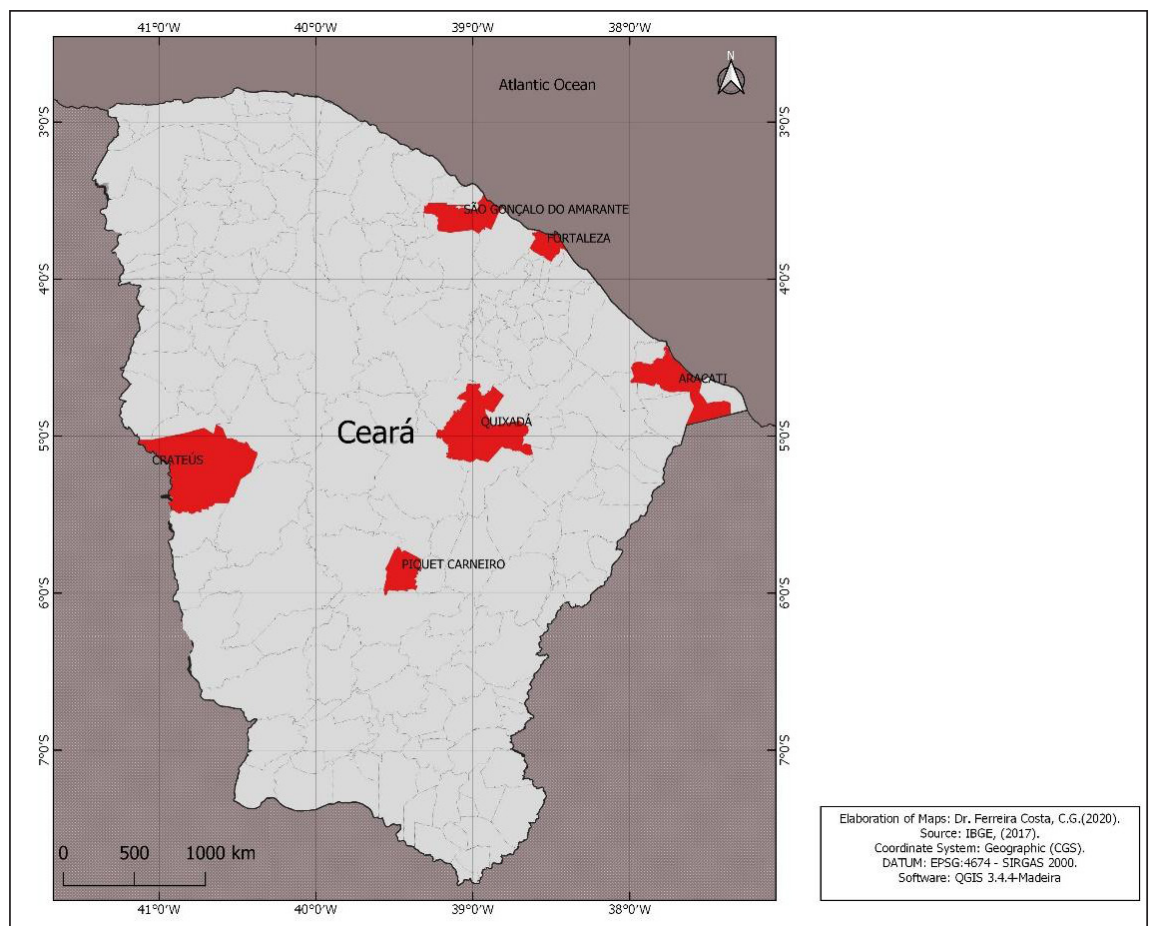

FIGURE 3 - Study Site Map.

SOURCE: Field Work. Maps Elaborated by the Authors of this Research. IBGE, 2017; QGIS 3.4.4-Madeira.

\footnotetext{
${ }^{4}$ We conducted out key interviews at the headquarters of the government bodies at the capital city of Fortaleza/CE to identify entry-points for investigation.
} 
sidered SALs in Brazil, with an exception made to Fortaleza -which does not fulfill the prerequisites to formalize as SALs according to SUDENE classification (2017). However, its importance as the nearest most populous urban area, and the site convening partners, state agencies and institutions headquarters, and coordination activities to create safer, and more resilient communities in Brazil's SALs, made it valuable study.

\subsection{Research Methods and Data}

We designed this qualitative research to assess experiential data regarding the extent of knowledge about specific laws, norms, policies, and practices in Disaster Risk Management (DRM) in Semi-Arid Lands of the State of Ceará, in Brazil. It is useful for measuring the quality and access to public service delivery, and supplement performance data collected from government agencies, which we expect, shed some light on bottlenecks and problems at the government-citizen interface (Wisner et al., 2020). Expert assessments were used based on administrative data and third-party reports, such as "evidence-based" state government reports and statistics employed to subsidize the mapping of institutions and DRM knowledge gaps on climate-risk management and resilience, as well as risk-informed local dynamics, where current understanding seems to be insufficient. The employment of the Case Study method in the context of Disaster Risk Management is related to the following situations:

(i) to describe a real-life context where sectoral public policies have been developed or are ongoing in different contexts and locations. (ii) assess the way multi-stakeholder partnerships interact in Disaster Risk Management processes locally; and,

(iii) compile data and assess information related to the Disaster Risk Management in Semi-Arid Lands (SALs) in a high-risk climate change 'hotspot' -the Caatinga.

To improve the understanding of sophisticated and contemporary climate change phenomena and risk reduction into policy planning -within its real context -in situations where the boundaries between the phenomenon and the context are blurred. We reviewed administrative data concerning the National Plan for Risk Management and Disaster Response, the National and State environmental legislation, and the Brazilian Atlas of Natural Disasters-Ceará's Chapter (MDR, 2012). We also assess environmental and specific DRR legislation, and reports of government bodies of the State of Ceará, such as the Agricultural Development Agency of the State of Ceará (SDA, for its acronym in Portuguese), FUNCEME, among others; aimed at assessing the quality of government resources, processes, and performance.

We gathered qualitative information through Focus Group Discussions (FGDs) and key informants' interviews conducted in loco in 2015. At the same time, we employed FGDs to assess qualitative data on institutional and organizational Disaster Risk Management capabilities to understand the application of available disaster management tools and their limitations. In this regard, we applied a multistage sampling procedure to assess the involved actors' ongoing DRR procedures and performance attributes. First, we defined the territoriality of the research in the State of Ceará 
in Brazil's northeastern region to contextualize the region's specificity under common climate change impacts according to the nationally official delimitation of Semi-Arid Land (SUDENE, 2017a; 2017b; 2020). Stage two consisted of selecting communities within this territory. We based it on key-interviews at the headquarters of the government bodies at the capital city of Fortaleza/CE. It was useful to identify entry-points for investigation and target the territories for analysis -totalizing 06 municipalities, resulting in the establishment of six Focus Group Discussions (FGDs - one in each municipality) to collect primary data, and to assess relevant information locally, using Institutional Perception Mapping (IPM) approach (WB, 2008). From the assessment of the interviewees regarding Disaster Risk Management processes taking place in the surveyed municipalities, the approach offered a basis for understanding DRM decision-making processes throughout parts of Semi-Arid Lands in the Northeast of Brazil. This approach was helpful to assess the identification of crucial relationships and factors affecting smallholder farmers and public institutions relationships dealing with Disaster Risk Reduction (DRR) in the State of Ceará (collected as narratives through the interview of municipal and institutional managers, as well as technical staff, specialists, and smallholder farmers).

Moreover, this approach sought to contribute to the understanding of Strengths, Weaknesses, Opportunities, and Threats to improve DRM in SALs, through SWOT Analysis; possibly, contributing to the future formulation of adjustment proposals capable of improving processes and instruments for identifying and responding to the occurrence of hydrometeorological disaster events. We oriented the analysis of the DRR institutional framework in the State of Ceará by bibliographic review of technical literature on the topic, and national and State legislation in the fields of Disaster Risk Reduction and Climate Change Adaptation; associated to the SENDAI framework (UNISDR, 2015), based on the AS/NZS ISO 31000:2009 Risk management norms, standards, and procedures for monitoring, emergency response, and resilient recovery (SNZ, 2020). In this research, we conceptualize the occurrence of disaster according to the Brazilian Disaster Classification and Codification (COBRADE) criteria (MDR, 2012; 2012a).

We sought to identify relevant public institutions and organizations (State and local governments and agencies, cooperatives, associations, NGOs, among others), and more importantly, their linkages, and weaknesses and strengths regarding disaster risk reduction, to assess how accessible and relevant these public institutions and organizations are in the building of adaptation and climate resilience in the context of SALs. At the beginning of the interviews, we discussed essential topics such as climate change adaptation, disaster risk reduction, local institutions, family farming, institutional relevance, and accessibility to public services and policies, to clarify concepts and any possible doubts regarding the study. We asked the interviewees to name all the institutions, approaches, or government projects they could relate to intervening in the area of disaster risk reduction, climate risk management, adaptation, and resilience-building at the local level. The identification of institutional relationships became possible by following the Institutional Perception Mapping (IPM) approach in the semi-structured interviews, built around the narratives found, along with the mapping of public institutions according to National and State legislation, as well as the 
literature review. The study also tried to assess the level of importance, accessibility, and relevance at the community and state levels of public actions in the field of Disaster Risk Management.

The FGDs were carried out in the selected municipalities in two different periods, between the last two weeks of January 2015 (between days 18 and 29); and, in March 2015 (between days 22 and 31). We interviewed key personnel (e.g., Directors, Monitoring/Evaluation Officers, Project Managers/ Team Leaders, Chiefs, among other available personnel) in the Capital city of the State, working on DRM on the mapped Institutions, and actors in the municipalities (Table 1), using a semi-structured questionnaire (Annex) and conducted the SWOT Analysis.

TABLE 1 - Selected Actors for Focus Discussion Groups.

\begin{tabular}{lc}
\hline \multicolumn{1}{c}{ Main Actors } & $\begin{array}{c}\text { Number of } \\
\text { Interviewees }\end{array}$ \\
\hline $\begin{array}{l}\text { Municipal Managers } \\
\text { Managers of Government Agencies }\end{array}$ & 5 \\
Involved with DRR in the State of Ceará & 6 \\
Municipal Technicians & 4 \\
Specialists (State Government) & 8 \\
Family Farmers with or without DAP & 27 \\
\cline { 2 - 2 } & Total: 50 \\
\hline
\end{tabular}

Further, the paper employs cartography for the best visualization of the specificities of the territoriality. For this, the QGIS software, version 3.3.4-Madeira, was used. The data source for shapefiles used was IBGE (2017), and SUDENE (2017). The reference system was the Geographic Coordinate System DATUM EPSG:4326-WGS84 used to compose the study areas' delimitation. General maps of the location of the Northeast Region, States, and Capital cities, as well as the distribution of SALs in the ter- ritory, had the goal of facilitating identification and observation of the study area. This research assumes that effective risk reduction and adaptative climate strategies must consider the territorial dynamics, physical and non-physical vulnerabilities, and exposure, and linkages to normative, evidence-based decision-making processes to support risk-informed climate-resilient development. These are critical and interdependent approaches to build adaptation and maintain resilience and sustainable socio-economic transformation (IPCC, 2014; UNISDR, 2015).

Summarizing: We used a combination of different methods to gain broader and more explicit information on the issues examined by this study. The methods used as follow:

- Interviews with 50 relevant counterparts as the state and local levels (listed in Table 1); insights obtained through the Institutional Perception Mapping (IPM) technique originated from Focus Groups Discussion (FGDs) (WB, 2008).

- Review of the laws, decrees, legal acts, and international and national agreements relating to DRR institutional and organizational frameworks, following the AS/NZS ISO 31000:2009 standards (SNZ, 2020).

- Review of scientific literature and official government documents relating to DRR, vulnerability, adaptation, and SAL's.

- Application of the methods of analysis of strengths, weaknesses, opportunities, and threats (SWOT analysis) (EU, 2020).

- Production of cartography for the best visualization of the specificities of the territoriality. For this, we use the QGIS software, version 3.3.4-Madeira. 
The application of these various methods was useful in collecting and recording the necessary data and information which we analyzed and served to shape the findings and recommendations found in this paper.

\section{Results}

This study aimed to assess existing State and local public institutions concerning their institutional relevance and performance on DRR performance in SALs, in Ceará, among indispensable interviewees. The collected data through the IPM technique followed a Focus Groups Discussion (FGDs) approach to support SWOT Analysis on the institutional framework that characterizes the study sites within the context of DRR and CCA. Chart 1 gives an overview of identified public institutions working -at state and local levels -, on DRR. The national and State legislation is clear in defining roles and responsibilities between institutions. The UGP-PDRS is the DRR managing body in the State of Ceará, while many of the listed institutions have been entrusted with the mandate to accompany smallholder farmers, intervening in various domains of climate change adaptation and risk reduction. Likewise, it has its merits in stating that these roles and processes, although influenced by "top-down" determinations, are distinguished by "bottom-up" approaches, in which the different public institutions in charge of DRR decision-making, planning, and implementation should connect, based on their respective areas of action to meet policy and implementation needs. In brief, public institutions are direct enablers of climate adaptation and resilience at the State level in Brazilians SALs, with a massive impact on normative frameworks, something that is described in more detail subsequently in this study.

The selected municipalities comprise a part of a Semi-Arid Lands with low socio-economic levels and offer a sample of the region's peculiarities when

CHART 1 - Identified Government Agencies with DRR mandates (Direct or Indirect).

\begin{tabular}{|l|}
\hline State and Local Level DRR Public Institutions \\
\hline UGP, PDRS -Projeto São José III (DRR Managing body in the State of Ceará) \\
Ceará Meteorology Foundation -FUNCEME \\
State Superintendence of Environment -SEMACE \\
State Council for Environmental Management and Policies -CONPAM \\
Brazilian Institute of Environment -IBAMA \\
Ceará's State Water Resources Management Company -COGERH \\
Municipal Councils for Civil Defense-COMDEC \\
Civil Defense Community Centers -NUDEC's. \\
Civil Defense of the State of Ceará \\
Civil Defense of Fortaleza
\end{tabular}


CHART 2 - Topics Covered in Qualitative Analysis.

Topic Covered in Qualitative Analysis -Semi-Structured Interviews

Importance and Use of Disaster Risk Management (DRM) Approaches in the State of Ceará.

Importance and Use of Disaster Risk Reduction (DRR) Tools in the Local Context.

Level of Understanding of Disaster Events, Reporting Instruments, and their Implementation at the Local Level.

Disaster Risk Management Procedures and Performance of Involved Institutions.

considering DRM. In effect, the selected municipalities are areas of traditional human occupation in the Caatinga biome, with a vast set of socio-economic, climatic, environmental, and institutional and organizational challenges and bottlenecks. The work is developed in a search to deepen the knowledge about the dimension DRR's political-institutional framework that is still relatively unexplored in SAL's in Brazil and worldwide. To subsidize the FGDs in the municipalities, we reviewed national and State DRR and environmental legislation, official documents, and interviewed representatives in State government agencies, which helped guide the topics covered in qualitative analysis (Chart 2).

\subsection{Focus Groups Discussion (FGD) and SWOT Analysis}

Both analysis tools -the Focus Groups Discussion (FDG) and the SWOT Analysis (EU, 2020) -assessed institutional, organizational, and technical gaps in Disaster Risk Reduction (DRR) capacity in SAL's, according to the municipalities. We assume that combining both tools can contribute to the discussions and improvement of Disaster Risk Management design-thinking and decision-making processes and social protection policy development in Semi-Arid Lands in Brazil and beyond. Current- ly, we expect to assess the actor's experiences on existing state and local DRR frameworks (Table 2). These gaps are both present in the internal and external structure of the State and municipal governments and, at least a priori, could be handled by improved governance at the Government level. Better communication channels between the different levels of public institutions and beneficiaries-State, regional, municipal (local) -involved in disaster risk management in the State of Ceará. It could reflect a better allocation of resources and less redundancy in efforts at the local level.

All municipalities are connected to or have representatives of each state public institution mapped (Chart 1). All households have access to DRR-related public institutions and policies. Respondents -regarding safeguarding knowledge, or access to Disaster Risk Management programs in the State of Ceará -, indicated vital areas of DRR actions and existing constraints to DRR knowledge and barriers to access related public policy and services at the local level (Table 3). Interviews indicated that DRR accessibility inequality, in the context of this research, might be due to inconsistent interventions when disasters strike -mostly drought events -leaving affected communities not entirely recovered after their impacts decrease. Local structural insufficiencies are not recognized and stopped, leaving exposed communities vulnerable to the next 
TABLE 2 - Interviewee's Perceptions of Existing DRR Frameworks.

\begin{tabular}{|c|c|c|c|c|c|}
\hline Municipality & Fortaleza & Quixadá & $\begin{array}{l}\text { São Gonçalo } \\
\text { do Amarante }\end{array}$ & $\begin{array}{c}\text { Piquet } \\
\text { Carneiro }\end{array}$ & Crateús \\
\hline $\begin{array}{c}\text { Perception of } \\
\text { DRM Actions at } \\
\text { the State Level }\end{array}$ & $\begin{array}{l}\text { A sufficient level of } \\
\text { Knowledge of the DRR } \\
\text { Management Process. } \\
\text { Open for Provide } \\
\text { Information. }\end{array}$ & \multicolumn{4}{|c|}{$\begin{array}{l}\text { Respondents are unaware of specific data and information on DRM, nor are there } \\
\text { response actions or risk reduction management (except actions against drought). } \\
\text { Respondents do not use data from IBGE or other official Federal and State surveys to } \\
\text { guide actions at the local level. } \\
\text { Respondents have low capacity to characterize disaster risk management in the } \\
\text { municipality and the State. } \\
\text { Respondents demonstrate a low ability to characterize family farming in the municipality. } \\
\text { They do not know all the federal programs related to the theme. } \\
\text { They do not know the Federal and State legislation specific to the areas of Environment, } \\
\text { Finance, and DRR. } \\
\text { Low level of training on DRR. }\end{array}$} \\
\hline
\end{tabular}

\begin{tabular}{cl}
\hline $\begin{array}{c}\text { Perception of the } \\
\text { Data Collection } \\
\text { and Survey }\end{array}$ & $\begin{array}{l}\text { Positive perception of } \\
\text { FUNCEME's performance. }\end{array}$ \\
$\begin{array}{c}\text { Processes for DRM } \\
\text { at the State Level }\end{array}$ & $\begin{array}{l}\text { Respondents point out the } \\
\text { need for improvements in } \\
\text { communication channels. }\end{array}$ \\
\hline
\end{tabular}

Lack of knowledge about procedures.

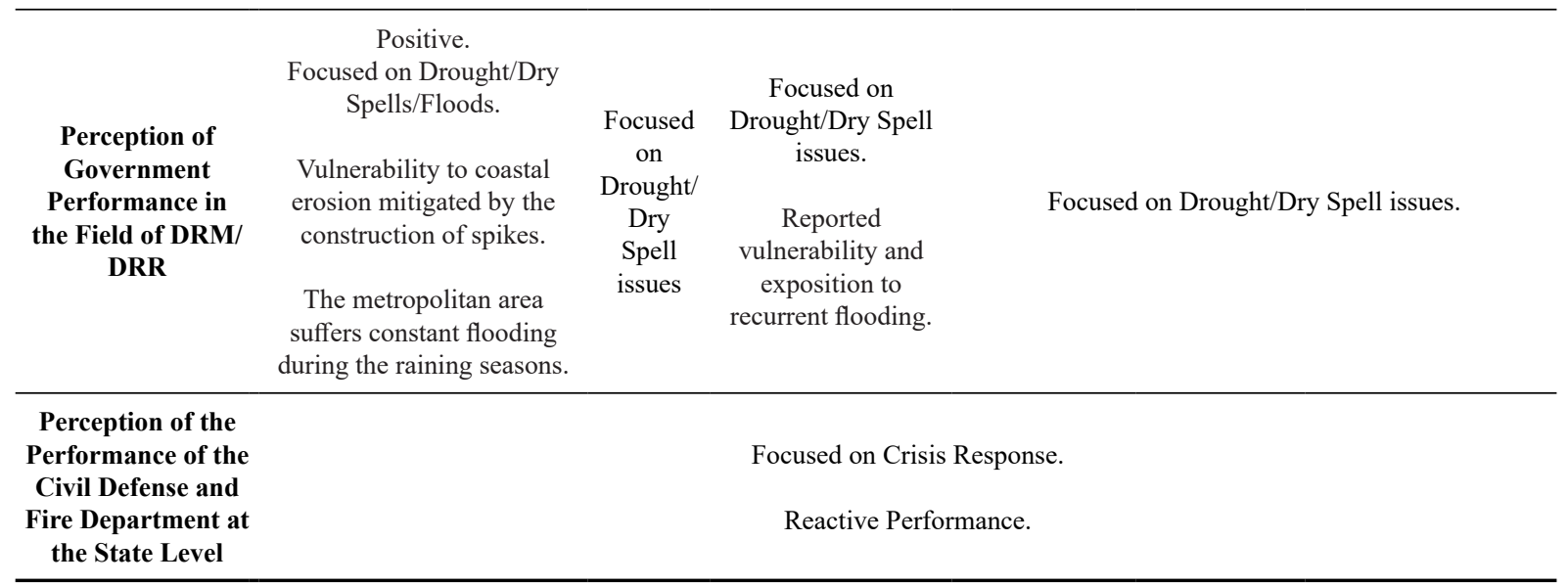

shocks of recurrent disasters. Although, there is unawareness of the continuation of public DRR/ CCA actions and policy implementation among households after the main impacts of events dissipate, and in some cases, unwillingness to partici- pate in some public interventions, if they demand time and an extra-effort, without visible personal benefits. 
Level of Knowledge and Access to DRR However, they demonstrate knowledge of government actions (Local and State) concerning Actions drought mitigation measures.

Respondents identify barriers to accessing public policies and services in this sphere.

\begin{tabular}{cc}
\hline Populations Affected by Disasters & Respondents do not demonstrate the capacity to identify the affected population. \\
\hline $\begin{array}{c}\text { Performance of the Civil Defense and } \\
\text { Fire Department (Local and State } \\
\text { Levels) }\end{array}$ & Respondents identify reactive response capacity. That is when the Drought/Drought crisis is \\
already installed. \\
$\begin{array}{c}\text { Perception of the Population on Topics } \\
\text { Related to DRM }\end{array}$ & It is insufficient, limited (in time, space, and scope) preventive actions, and preparedness for \\
disaster events.
\end{tabular}

When asked to cite public agencies promoting DRM in some of their ongoing activities in the State of Ceará, the respondents maintained a certain homogeneity in the responses. They could identify public institutions ${ }^{5}$ Locally implementing policies crossing some areas of DRM and livelihood resilience-building such as FUNCEME, SEMACE, IBAMA, Civil Defense of the State, Municipal Councils of Civil Defense (COMDECS), COGERCH, and the Secretariat for Agrarian Development (SDA) -all identified as active or very active in the sphere of response to hydrometeorological events in the assessed territories. However, it was difficult to point out the ways they deliver services in this field. Nonetheless, they were assertive in mentioning public institutions less active in DRR implementation -Rural Unions and Associations, EMATER, and Municipal Secretariats of Agriculture, in this order. They were unable to identify the existence of Civil Defense Community Centers (NUDEC's), and Municipal Councils for Civil Defense (COMDEC's), which should play essential roles in DRR at the local level, according to the national and State legislation.

Regarding the profile, insertion, and motivation of these actors, the respondents showed a negative perception of the DRM policy implementation of actions at the local level. It might indicate unsatisfactory DRR implementation strategies and lack of articulation among more active partners -mostly due to reactive approaches -, in terms of authority and the direct links maintained within municipalities and beneficiaries (Table 4).

A critical look at Table 5 reveals that, although the State of Ceará has an established DRR framework, funds, and institutional capillarity, DRR actions not always reach those most in need, on time. This reality is mainly attached to constraints related to limited human, logistical, and financial-readiness capacity; aspects pointed by experts working in institutions linked to DRM in the State of Ceará.

In this research, institutional support represents all the activities and initiatives provided

\footnotetext{
5 The institutions mentioned earlier are known as resource controllers or communicators, bridging national and State DRR networks (as well as other formal public policies and actions) as they lay between two or more administrative levels.
} 
TABLE 4 - Profile, Insertion, and Motivation of Actors Involved with DRM in the State of Ceará.

\begin{tabular}{ll}
\hline Municipal Managers & $\begin{array}{l}\text { Presents little interaction on issues related to DRM. } \\
\text { Lack of prevention and preparedness actions. }\end{array}$ \\
\hline Municipal Technicians & $\begin{array}{l}\text { Demonstrate little initiative, driven by the political motivation of hierarchical superiors. } \\
\text { Limited and outdated technical knowledge. } \\
\text { Few opportunities for training (Very expensive when available). }\end{array}$ \\
\hline Rural Unions and Associations & Political motivation and use of government actions. \\
\hline \multirow{3}{*}{ Financial Institutions (Bank of Brazil and } \\
Caixa Bank) & $\begin{array}{l}\text { High capillarity, but with limited access for most of the population. } \\
\text { Limited availability of information in a form that can be understood and used by vulnerable } \\
\text { populations. } \\
\text { Meet banking operation goals. }\end{array}$ \\
\hline Smallholder Farmers & $\begin{array}{l}\text { They identify actions related to productive activities and related to PRONAF. } \\
\text { Overall Populations }\end{array}$ \\
$\begin{array}{l}\text { Uninformed and disinterested on the topic of DRM. } \\
\text { Except during the occurrence of drought or dry spells events. } \\
\text { There is no proactive action mindset. }\end{array}$ \\
\hline Interaction Among Key Actors & $\begin{array}{l}\text { Commonly nonexistent. } \\
\text { Frequent, in times of drought, agricultural pests, and floods. }\end{array}$ \\
\hline
\end{tabular}

TABLE 5 - Human, Logistical, and Financial Capacity Gaps

\begin{tabular}{ll}
\hline & $\begin{array}{l}\text { Committed, but facing technical/financial limitations. } \\
\text { In need of better training and external support. }\end{array}$ \\
$\begin{array}{ll}\text { Profile and posture of the technical } \\
\text { professional linked to DRR }\end{array}$ & $\begin{array}{l}\text { Lock of adequate equipment and work material. } \\
\text { Poor work infrastructure. } \\
\text { Lack of adequate staff. } \\
\text { External dependency (State and Federal). }\end{array}$ \\
\hline $\begin{array}{ll}\text { Knowledge of, and the ability to use Disaster } \\
\text { Risk Management tools }\end{array}$ & $\begin{array}{l}\text { Generally speaking, limited. However, with great familiarity with local events, such as } \\
\text { droughts, dry spells, and floods. }\end{array}$ \\
\hline $\begin{array}{l}\text { Understanding of disaster event reporting } \\
\text { instruments and their applications }\end{array}$ & $\begin{array}{l}\text { Insufficient. Respondents are unaware of online Federal and State risk management tools. } \\
\text { At the local level, there are no such tools available. }\end{array}$ \\
\hline $\begin{array}{l}\text { As for the notification/classification process } \\
\text { for the occurrence of events at the local level } \\
\text { (Drought Emergency Declaration)? }\end{array}$ & $\begin{array}{l}\text { Yes, they identify mechanisms for reporting drought emergencies, delineated as a centralized } \\
\text { process. They believe it is a process that is continuously under political pressure. Generally, } \\
\text { related to the inclusion of beneficiaries in categories suitable for receiving Federal aid and } \\
\text { participation in income transfer programs. }\end{array}$ \\
\hline $\begin{array}{l}\text { Disaster Risk Management Procedures and } \\
\text { performance characteristics of the entities } \\
\text { involved }\end{array}$ & $\begin{array}{l}\text { Flawed and limited in scope. } \\
\text { Reactive response and emergency. }\end{array}$ \\
\hline
\end{tabular}

by existing public institutions. According to the interviews (experts), public institutions in the State of Ceará are aware of the risks posed by climate change to human development and productive assets in SALs. In this regard, the SWOT analysis (EU, 2020), sought to identify the institutional and organizational weaknesses, and indicate some of its strengths; the respondents were very clear in identifying the most promising areas related to monitoring in Meteorology, Water Resources, Agrarian Development, and Environmental preservation in the State of Ceará. 


\subsubsection{Strengths}

Stallholder farmers have reported benefiting both tangible and intangible resources, including financial support (credit and loans), and social protection (Mostly related to Federal policies, such as National Program for Strengthening Family Farming (PRONAF), Programa Garantia Safra, Bolsa Estiagem, Bolsa família, among others). In the local public institutional core, FUNCEME, COGERH, and EMATER offices seem to be positively perceived. Although positively identified, the last one is somehow noted as ill-equipped to endeavor to continue adequate assistance in moments of high demand. Besides, the respondents stated the inadequacy of rural technical assistance, no employment of modern technologies, and the necessity of strategic and structured action coupled to the absence of personnel and support as crucial factors limiting institutional purpose at the local level. Nevertheless, regarding the process of notification/classification of disaster events used by the civil defense, there is a comprehensive understanding that the government works in partnership with the National Secretariat for Civil Defense and Protection (SENPDC) for training and dissemination of the Integrated Disaster Information System (S2ID) with the National Secretariat of Civil Protection and Defense (SEDC).

\subsubsection{Weaknesses}

Regarding the acknowledgment of federal/ state government programs linked to DRR, the respondents consider that, in a certain way, the government is competent in administering and implementing DRR services and actions, yet, in a very modest and reactive way. The most broadcasted DRR actions are still those correlated to drought response.

We identified the representative groups of smallholder farming (rural associations, cooperatives, unions) as fragile and experienced internal and external interference in political authority and partisan exploitation of vulnerable rural groups. These factors linked to institutional and organization gaps create a drive for the political use of public DRR actions, funding, and social protection policies. It needs to be tackled urgently in the implementation of improved Integrated Disaster Risk Management processes in SALs.

In this regard, respondents raise critiques regarding COMDEC'S unclear DRR action, and unfamiliarity of Civil Defense Community Centers (NUDEC's). Respondents described the first institution as having a highly reactive method of support when a disaster strikes. In general, institutions like the COMDEC and NUDEC should benefit from closeness to beneficiaries (MDR, 2012). Nevertheless, it demands organizational capability and sustained political will at the various levels they operate.

According to the FGDs, family farmers demonstrated little skill/little interest in forms of joint/community work. Family farmers and those who interact with the land in meaningful forms gain power when jointly responding to market forces. The disinterest in articulation as a cohesive group undermines them as a viable political force and makes room for intermediaries and political exploitation of the class. Also, it limits the likelihood of flourishing community-based disaster risk management. In this study, we did not distinguish spontaneous social arrangements as essential actors 
in DRR and CCA at the local level. Instead, formal public institutions perform a pivotal role in these viewpoints. This divergence highlights the contextual landscape of DRR action and climate-resilience building comprising the adaption level and domain (Yomo et al., 2020).

\subsubsection{Opportunities}

On the other hand -regarding the most traditional approaches to technical assistance -government agencies responsible for social protection, and agricultural sector resilience-building presented a strong focus on meeting repressed demands for water and staple foods, indemnity for agricultural losses (e.g., the Programa Garantia Safra), and income transfer (Bolsa Estiagem, Bolsa Família), among others. Part of the findings allowed us to affirm that Federal social protection programs, such as PRONAF, are the main instruments effectively supporting economic activities during and after disaster events among the interviewed rural populations. Almost all smallholder farmers considered it favorably. However, some of the respondents commented about the high cost/benefit ratio of access to some of these programs - possibly indicating the political exploitation of vulnerable rural populations regionally. Besides, respondents find it challenging to identify existing financial mechanisms concerning agricultural price volatility ${ }^{6}$ in the occurrence of events, the integration of such factors and processes could blueprint and contribute data and information that may be useful for future disaster response and proposals aimed at improving the Risk Management process in the State of Ceará and other SALs. Unfortunately, public institutions addressed these issues unsatisfactorily. It became clear that the impact of a changing climate and social protection programs demands an in-depth comprehension of the SALs' circumstances, and such issues must be explored and thoroughly studied in future research.

\subsubsection{Threats}

In general, the interviewees cited droughts, dry spells, and floods as the principal occurrences of disasters in the State of Ceará. Drought, to its frequent occurrence, is commonly not considered a "disaster," highlighting the limitations of learning processes and historical understanding of drought impacts at a community level. These are crucial factors limiting the socio-economic development in vast areas in SALs, mostly because it has some effect on the lack of capacity to establish preparatory actions to prevent adverse consequences of droughts and other related shocks on food and nutritional security.

The interviewees were not able to distinguish the current DRM/DRR legislative baseline in Brazil, nor that established in the State of Ceará. Neither the support lines provided by the different government agencies operating in the territory, excepting when it is related to drought episodes. They recognized the advantages of having preparatory, preventive, and contingency planning processes developed and implemented at the local level to bypass and restrict

\footnotetext{
${ }^{6}$ The National Food Security Council (Consea) proposed creating the National Food Price Observatory in 2011. However, Brazil's current structure of public interventions is conducted according to the developments in the conjuncture of agricultural commodity markets.
} 
the suspension of essential services, damage $\&$ loss (D\&L) of productive assets, preserve livelihoods, and incite their quick re-establishment. Respondents implied that more proactivity and less reactivity should be the central pillar of DRR public actions, followed by the identification/hierarchization of responsible institutions and organizations, risk assessments, mobilization of human, material, and intersectoral resources. It might suggest that there is a growing understanding of the benefits of integrated Disaster Risk Management processes in the
State of Ceará, by strengthening pre-disaster actions (prevention, and preparation) and mitigation, as opposed to post-disasters (reactive response, and unsustained recovery processes). However, barriers may exist in implementing DRR and adaptation strategies, policies, and measures. These may be due to resource constraints and governance issues, since adaptation occurs at different levels in society, including the local level in several different contexts (Russel et al., 2018). A close look at Table 6 summarizes the SWOT analysis of public institutions

TABLE 6 - SWOT Analysis of DRR Public Institutions in the State of Ceará

\begin{tabular}{|c|c|}
\hline \multirow{6}{*}{ Strengths } & $\begin{array}{l}\text { Hydrometeorological events monitoring presents a very positive evaluation, a high degree of reliability, and works } \\
\text { satisfactorily. }\end{array}$ \\
\hline & $\begin{array}{l}\text { Drought response and government actions to sustain livelihood in SALs and public income transfer policies have } \\
\text { contributed to reducing the vulnerability of communities (Federal action, and to a lesser extent, State actions). }\end{array}$ \\
\hline & $\begin{array}{l}\text { Local and State governments are always mentioned positively, both in water management, drought response, and rural } \\
\text { development. }\end{array}$ \\
\hline & Governmental actions and their employees are respected and prestigious. \\
\hline & There is a spirit of trust on the part of the population. \\
\hline & Respondents believe in the information provided by Government Agencies. \\
\hline \multirow{9}{*}{ Weaknesses } & Lack of adequate and continuous support from government agencies. \\
\hline & Lack of investment in personnel, qualifications, and work material. \\
\hline & Lack of information from both agents and the general population about modern DRM practices. \\
\hline & External dependence on the part of the municipalities and population (State and Federal). \\
\hline & $\begin{array}{l}\text { Low level of political articulation for Disaster Risk Reduction and Climate Change issues, and their inclusion into } \\
\text { national and regional development policies. }\end{array}$ \\
\hline & There is no systemic view of the problem. Actions are punctual, and often unordered, and overlapped. \\
\hline & They have limited DRR institutional capability at the local level. DRR Policy insufficiencies at the State level. \\
\hline & $\begin{array}{l}\text { Several government actions, directly and indirectly, aimed at the area of Disaster Risk Reduction Management, overlap, } \\
\text { generating a loss of revenue, operational inefficiency, and opportunity for corruption. Besides, some processes are } \\
\text { complicated and bureaucratic. }\end{array}$ \\
\hline & Insufficient institutional communication capacity (communication channels). \\
\hline \multirow{3}{*}{ Opportunities } & $\begin{array}{l}\text { Proper levels of approval of the state government regarding its policies, recognition of its actions in drought and territory } \\
\text { management, opening space for cooperation, and technical-financial support channels from different international and } \\
\text { national organizations and communities. }\end{array}$ \\
\hline & Openness to integrate Non-Governmental Organizations and Civil Society Organizations. \\
\hline & $\begin{array}{l}\text { The creation of a DRR/CCA Secretariat for the Climate-related Disaster Risk Reduction Management involves different } \\
\text { sectors and institutions, both at the local and State levels. }\end{array}$ \\
\hline \multirow{3}{*}{ Threats } & Shortness of well-trained and stable technical staff at the local level. \\
\hline & Lack of municipal secretariats specifically focused on the issue of Risk Reduction and Climate Change Management. \\
\hline & Unawareness of standard procedures and norms for Disaster Risk Reduction Management. \\
\hline
\end{tabular}


with mandates covering some, or all, aspects of DRR and CCA in the State of Ceará.

Adopting preventive agrometeorological strategies can diminish the negative impact of climate change on agriculture and society, such as improving agrometeorological networks. The establishment of efficient agrometeorological databases and ensuring timely dissemination of Early Warnings Systems to natural and human-made hazards in rural settings. Besides the promotion of scientific research on climate extreme risk patterns at the local level (Hatfield et al., 2018).

\subsubsection{Challenges and opportunities}

Respondents recall that it is still necessary to disseminate the culture of Civil Defense at all levels, starting with managers and directors in government institutions and organizations. Also, to provide the strengthening of the integrated management capacity of climate-related risks, under an Integrated Risk Management (IDRM) framework, both at local and regional levels. It would be necessary to implement broad dissemination of DRR awareness-raising programs among the population, integrated with train- ing in planning, monitoring, and evaluation, among professionals who deal with disaster management and response in the State of Ceará (Table 7).

The most significant challenges and bottlenecks identified in the DRM in the State of Ceará can be related to insufficient intersectoral integration, insufficiencies in training, research, and rural extension that can be correlating to uncoordinated implementation of DRR activities in the territory. Besides, undefinition regarding which climate scenarios and statistics are now in use impacts the assessments of progress on adaptation (Alves et al., 2020). The fragility of investments and insufficiencies regarding institutional, organizational, and technical capacities account for an immense toll on the lack of Municipal Civil Defense Coordination -COMDEC's -, and the ineffective contribution of civil society through the Civil Defense Community Centers -NUDEC's. In brief, respondents reported that their interaction with public institutions, regarding DRR actions, had a limited impact in their capacity to prepare and cope with droughts and floods events since many of these interplays are limited to the moments when disasters strike, based in a reactive pattern of response, exposing

TABLE 7 - DRR Potentialities and Challenges in the State of Ceará.

\begin{tabular}{ll}
\hline & Technical/institutional/legal elaboration of action plans and early preparation for disaster events and anti-corruption \\
actions are feasible. & Establishment of multisectoral and intergovernmental partnerships for the elaboration and implementation of local- \\
Potentialities & Oevel DRR plans. \\
& Opportunities offered for social protection and DRM in the State of Ceará. \\
\hline & Improvement of communication channels. \\
& Reinforce and invest in infrastructure and Early Warning Systems (Drought Monitor). \\
Review and update the regulatory and legal framework. \\
Hire, train, and maintain technical staff and professionals, both in terms of DRR and cross-cutting areas, given \\
fiscal limitations.
\end{tabular}


the tensions and the gaps between climate policies and their adequacy and implementation (Alves et al., 2020). Moreover, most of the beneficiaries commented on a minimal smallholder farmer's capacity to participate and influence decision-making processes. The integration of beneficiaries in these processes, considering their groundwork experience could be helpful to re-shape government interventions and institutional and organizational framework since the respondents confessed their trust in state government institutions. A close look at Table 8 identifies common bottlenecks to achieve desired potentialities and respond to DRR challenges at the state level, according to respondents.

TABLE 8 - DRR Bottlenecks in the State of Ceará.

\begin{tabular}{cl}
\hline Challenges to Reduce Vulnerability of Populations \\
\hline \multirow{2}{*}{ Income } & $\begin{array}{l}\text { Increase the DRR capacity to generate income } \\
\text { through production and support services. }\end{array}$ \\
\hline \multirow{2}{*}{ Markets } & $\begin{array}{l}\text { Facilitate market access. } \\
\text { Strengthen farmers' organizations } \\
\text { (associations, cooperatives, unions). }\end{array}$ \\
\hline $\begin{array}{c}\text { Research, } \\
\text { Development, } \\
\text { and Innovation }\end{array}$ & $\begin{array}{l}\text { Eliminate the factors that perpetuate poverty } \\
\text {-through investments in the education of } \\
\text { rural children, youth, and adults by providing } \\
\text { specialized professional training in rural areas } \\
\text { agriculture). }\end{array}$ \\
$\begin{array}{l}\text { The government should encourage the } \\
\text { development of "startups" aimed at developing } \\
\text { technology and solutions for socializing and } \\
\text { production in semi-arid regions. }\end{array}$ \\
\hline
\end{tabular}

\section{Discussion}

The Intergovernmental Panel on Climate Change (IPCC) defines adaptation as a "process of adjustment to actual or expected climate and its effects. They acknowledge that around the human-made system, adaptation endeavors to modify resource impairment or bring and utilize advantageous possibilities" (IPCC, 2014, p. 118). The diffusion of these adaptation tactics, nonetheless, depends on the adaptive capacities of all actors and their control over both tangible and intangible resources (Dixon et al., 2014; Hogarth \& Wójcik, 2016). However, understanding if and how adaptation is taking place remains limited and fragmented (Ford et al., 2015). Besides, there is still a considerable research gap on the roles of institutions or community-based organizations to different forms of adaptation and in enabling or facilitating climate change adaptation (Aboniyo \& Mourad, 2017; Ngonyani \& Mourad, 2019). Globally, local institutions commonly play critical roles in shaping the response to climate change (Amaru \& Chhetri, 2013; Butler et al., 2014; Mubaya \& Mafongoya, 2017; Yomo et al., 2020).

Brazilian environmental legislation is one of the most modern in the world, while DRM legislation is advanced (MDR 2012; 2012a). Since the promulgation of the 1988 Constitution of the Federative Republic of Brazil, it experienced several political transformative actions. Paragraph XVIII of Article 21 of the Federal Constitution established that the Union is responsible for "planning and promoting permanent defense against public calamities, especially droughts and floods." To this end, the federal government instituted in 2012, the National Civil Defense Policy (PNDC), whose objective was, in the first instance, to promote actions aimed at producing disaster reduction (MDR, 2012). For the implementation of the PNDC, the National Civil Defense System (SINDEC) explicitly follows Constitutional policy instruments. The 
bases of Civil Defense Planning are the Master Plans for Civil Defense, at the municipal, regional, and federal levels. These are implemented through specific programs considering the following global aspects (disaster prevention; emergency and disaster preparedness; disaster response; and sustainable and improved reconstruction -Build-Back-Better concepts). Community participation plays an essential role in disaster prevention, not only to be aware of the hazards but also to charge public authorities for minimizing risks. In this regard, the Community Municipal Councils for Civil Defense (COMDECS) aim to develop a permanent orientation process with the population (MDR, 2012a). They have as main objective the prevention and minimization of risks and disasters in the most vulnerable areas in the municipalities (Figure 4).

It is worth noting that the rules that regulate Civil Defense, regarding the identification and operation of DRR actions on the national territory, and the issuance and cataloging of disaster events are standard for the whole country. However, adaptation gaps, behavioral barriers, and market failures hold back effective adaptation requiring coherent policy intervention (Fankhauser, 2017), as National policy development does not always result in local implementation or policy (Alves et al., 2020).

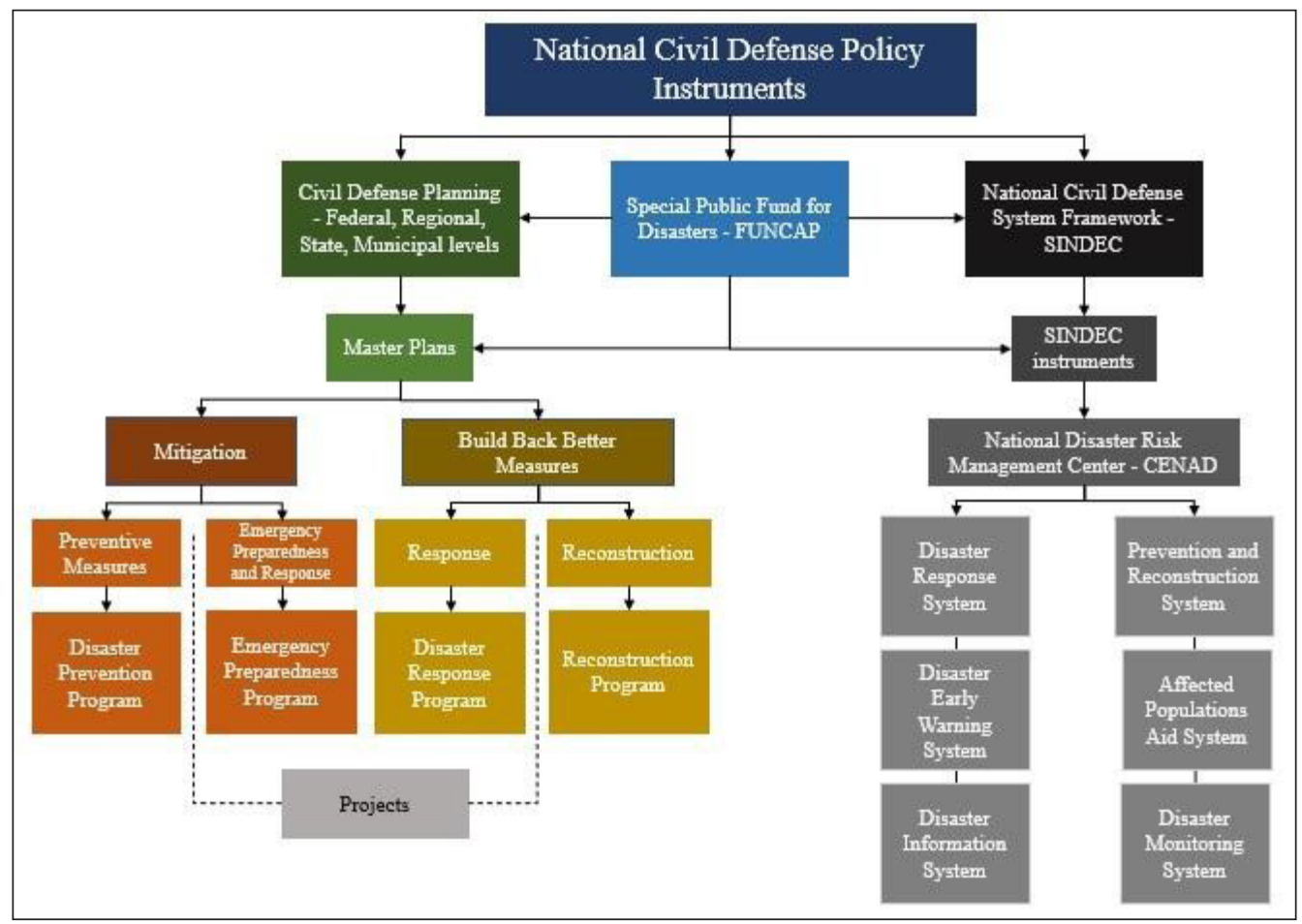

FIGURE 4 - Brazil's Civil Defense Framework.

SOURCE: MDR, 2012. 
The National Secretariat of Civil Protection and Defense (SEDC) carries out Disaster Risk Management in the State of Ceará. It was created by Decree No. 28.391, of September 13, 2006, and reorganized by Decree No. 28.656, of February 26, 2007. The SEDC consists of bodies and entities that are part of the state administration, private entities, and the community in general, under the coordination of the State Civil Defense branch, an organ belonging to the organizational structure of the Military Fire Brigade of the State of Ceará (CBMCE). Besides, the State of Ceará counts with an Integrated Disaster Risk Management Plan for the whole State (PIGRD-CE), developed by the Secretariat for Agrarian Development of Ceará (SDA), and the World Bank through the Sustainable Rural Development Project -PDRS/São José Project (SDA, 2015). In this regard, the IICA(2015) offers a complete analysis of the institutional framework in Disaster Risk Management (DRM) and related environmental and financial legislation in the State of Ceará and Brazil. Fortaleza's city has preparedness and response plans in place, ready to address the impacts of disaster events. However, these plans are sectoral oriented, private, and limited in scope. Experts mentioned the existence of plans among the following companies: Tanking Park/LIQUIGÁS/PAM, INFRAERO/EXEAC, as well as the Fortaleza's COMDEC (at a public level), regarding floods response (plans and simulation initiatives); and, lately at the municipality of Piquet Carneiro (2016), in a pilot project with the World Bank in association with the SDA-CE for Community-Based Disaster Risk Management (CBDRM) (WB, 2019). In overall, Ceará's State DRR preparedness and prevention actions, in the nexus of climate change, are seeking to increase agricultural and socio-economic resilience through (i) climate surveillance and weather monitoring; (ii) a better understanding of vulnerability/resilience ratio; and, (iii) improved coordination and systematic response planning, represented by the development of an Integrated Disaster Risk Management Plan (PIGRD-CE), and Early Warning Systems (Drought Monitor), and by establishing enhanced political coordination and articulation among governments agencies and partners, embodied in a state-level "Drought Committee" (IICA, 2015; SDA, 2015; Ferreira Costa et al., 2016; WB, 2019).

\section{Limitations and suggestions for further research}

The study investigated existing public DRR institutional and organizational frameworks at state and local levels. Measuring the relationship of institutional frameworks, and their influences on livelihood sustainability and resilience are not readily accessible. Sustainability and resilience are both complex and continuously evolving phenomenon, so is institutional organization. Both sides show many patterns of performance of numerous actors and determinants, including socio-economic and cultural settings, institutional and organizational structures, political environments, and economic and structural policies. Thus, weighing these factors depends on what information regarding sustainability and resilience we strive to cover, and under which circumstances. In the end, it is about power relations to document the ways actors seize the leadership challenges and conflicts. An excellent point to remark is that these power relationships are slightly opaque and notably challenging to apprehend with 
certainty and correctness. Understanding the nature of data and its constraints restricts its misapplication, such as misleading or erroneous deductions or generalizations on the status of institutional and organizational progress. Intricate conceptions rarely can be measured immediately by single methods. We believe the addressed subject needs additional investigations. Especially, in-depth research concerning network analysis and standards, statistics calculation, and network visualization, detailing the power, influence, and authority of a more representative web of actors, including other governmental and non-governmental institutions, considering the direct and indirect number linkages maintained within SALs; probably using specific software (e.g., Gephi or Kumu), allowing the visualization of the mapped network. The topic inquired could also benefit from the increase of the geographical scope, incorporating a more significant number of municipalities, in different perspectives, and administrative levels, to ensure a more comprehensive sample size informing political choices thoroughly, as we question local level involvement and roles in the co-production of adaptation policies (WB, 2009).

\section{Recommendations}

Semi-Arid Lands, especially in Brazil, receive limited attention in international climate research and policy, as well as in proactive disaster preparedness and preparation at national and local levels (Huang et al., 2015; WMO/GWP, 2017; Gannon et al., 2020). Moreover, this is felt, mainly, in the limited availability of quality scientific production. We seek to contribute to an ongoing discussion to better understanding the threats to adaptation we face (Di Gregorio et al., 2019; Alves et al., 2020) and hoping to contribute to foundations and bases for more in-depth and better-contextualized research. With this work, we seek to outline a context for future research. The combination of Focus Group Discussions, key informants' interviews, and review of DRR legislation comprising both public institutions and smallholder farmers shed some light on how these institutions can further integrate climate adaptation and resilience, and risk reduction in SALs, guiding government risk-taking approaches and changing patterns of behavior. What might help decision-makers to accelerate their DRR involvement and actions, supporting transparency, accountability, and integrity, providing higher standards for beneficiaries participation, and equal access to distributive and restorative justice and fairer decision-making processes, leading to what expect to be the initial steps for a required societal transformation? Remains an open question.

Furthermore, addressing climate change challenges through only one lens (either mitigation or adaptation) can lead to trade-offs, and one could undermine the other (IPCC, 2007). It should be related to a consensus around DRR proactive preparedness and vulnerability reduction approaches, and not only emergency response (Wisner et al., 2020). In this regard, considering these interactions through stakes interests, knowledge, resources, and networking capability does not guarantee equity, fairness, or acceptance (UNDP, 2004; Torfing et al., 2012; Ojwang et al., 2017).

Although the inefficiencies of the Disaster Risk Management processes observed concentrated in areas of high governance of state and municipal governments, the reduced organizational and technical capacity of local communities results, 
in most cases, in the negligent application of measures and resources to address local DRR demands. Since policy actors mostly interact within levels, and jurisdictional boundaries produce obstacles to cross-level interaction and reinforce mismatches between governance systems and responses (Di Gregorio et al., 2019). Many municipalities cannot deliver satisfactory outcomes independently. In this way, we recommend some actions according to the lessons learned based on the roles played by existing government institutions regarding DRR, CCA, and Social Protection, paying more attention to local contexts, their vulnerabilities, specificities, resources, and to find tailored solutions (Alves et al., 2020). Besides, understanding local DRR frameworks is essential in better allocating resources and risk-informed initiatives in dryland areas (Table 9).

The assessment of institutional and organizational frameworks is crucial to accurately monitor the weaknesses and strengths of DRR and CCA

TABLE 9 - Measures to Improve DRR Decision-Making Processes in SALs.

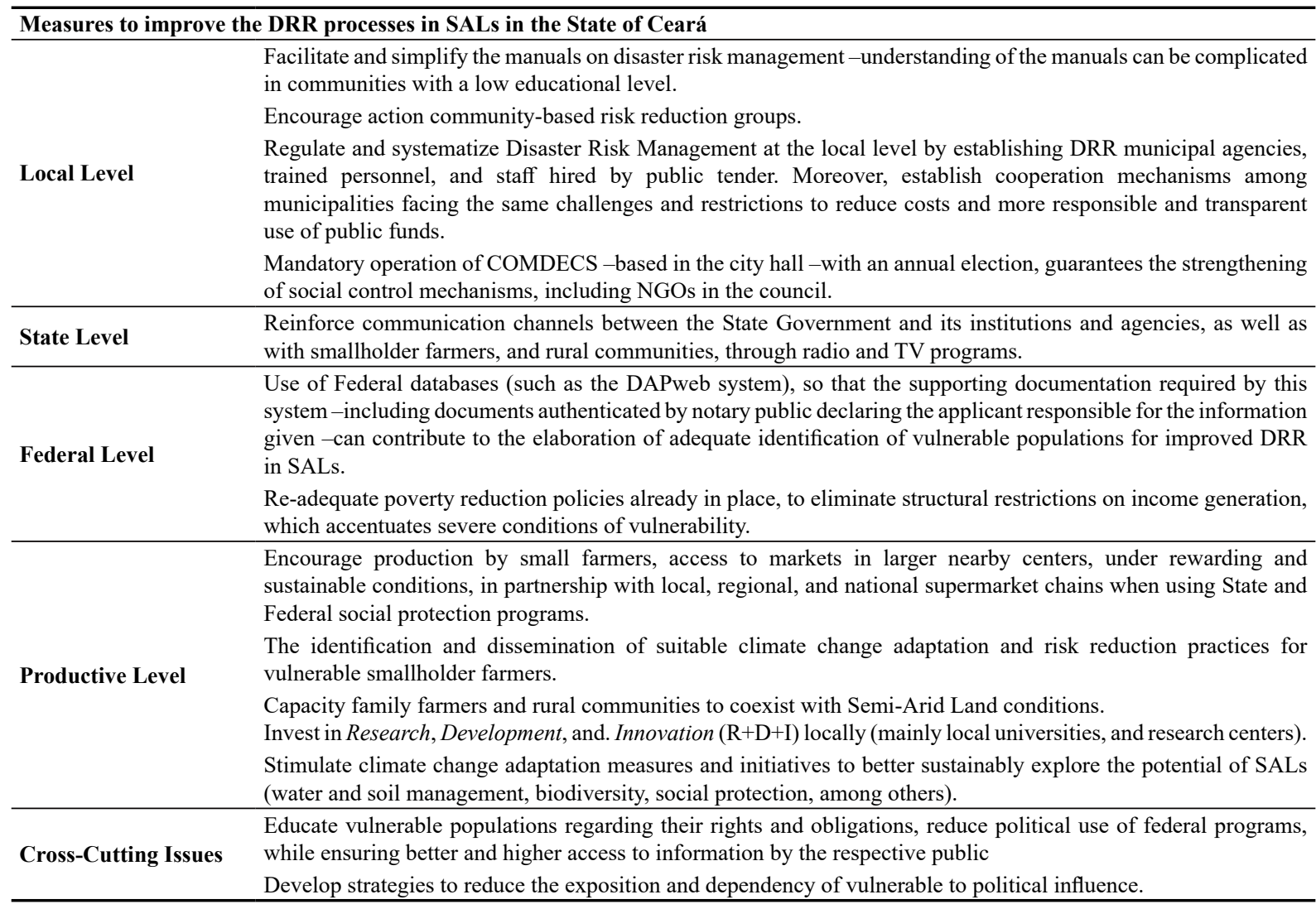


efforts in SALs, but they are not always straightforward. They can help illuminate legal and policy frameworks, institutional arrangements, processes, mechanisms, practices, outputs, and outcomes associated with investigated concepts (Wisner et al., 2020). However, identifying what should exist to improve established frameworks in terms of giving indications regarding transparency, accountability, and integrity within a given network demands more time and resources.

Monitoring institutional and organizational weaknesses and strengths is useful for assessing the effectiveness of political decision and policy implementation (EU, 2020). Nonetheless, institutional and organizational weaknesses and bottlenecks remain a crucial challenge in terms of the necessary adequacy of climate risk management in the face of current and future challenges posed by climate change, which accelerates the need for transformational change (Ferreira Costa et al., 2016).

\section{Final considerations}

This paper contributes to the growing knowledge of the institutional framework's role in the facilitation of local adaptation. The paper introduced an innovative approach for the analysis of governance practices in SALs, attempting to link Disaster Risk Reduction (DRR), climate change adaptation (CCA), and social protection policies and services into design-thinking and planning processes at all levels. The impacts of climate change are anticipated, by scientific research, to increase in the coming years, especially in Semi-Arid Lands (SALs). The pursuit of additional investigation in SALs environments, especially in the Caatinga -, helps to monitor and evaluate how public institutions and civil society are meeting their sustainable development and climate goals and targets under the 2030 Agenda and the Paris Agreement. Since local communities are at the core of disaster risk reduction, and community-based approaches are getting focus on national and regional DRR/CCA planning processes, as observed in National Adaptation Plans/National Adaptation Strategies -NAPs/NASs. This research revealed what seems to be working well, what is not, how things could be improved, and what remains for that improvement regarding DRR/CCA actions and planning processes at various levels over time in a large portion of Brazil's SAL. This study plays a crucial role as a useful learning tool to analyze the strengths and weaknesses of institutional and organizational inefficiencies in DRM, especially in SALs. It identified and proposed solutions to correct errors highlighting good practices as essential steps to understand and tackle local policy implementation needs in our fast-changing world.

\section{Acknowledgment}

Special thanks to the Project Management Unit (UGP in Portuguese), of the Projeto São José III -PDRS. The project management agency implementing DRM actions in the State of Ceará, and the Inter-American Institute for Cooperation on Agriculture (IICA). Also, to the FUNCEME; the SEMACE; the CONPAM; the IBAMA; the Civil Defense of the State of Ceará; The Civil Defense of Fortaleza; The COGERH; and, the COMDEC of Fortaleza city. The views in this paper are the authors' views and do not necessarily reflect the views or policies of the Institutions, Organizations, 
its Board of Directors, or the Governments they represent. Since the reviewer's inputs have been precious for a successful publication, we would like to acknowledge their contribution explicitly, regarding their time reviewing this research paper. Therefore, we would like to thank them for their thoughtful comments and efforts towards improving the paper to the present level.

\section{References}

Aboniyo, J.; Mourad, K. Role of Community-Based Organizations in Transferring Climate Change Information in Rwanda. Research Journal of Environmental Sciences, 11(4), 156-169, 2017. doi: 10.3923/rjes.2017.156.169

Alves, F.; Filho, W. L.; Casaleiro, P.; Nagy, G. J.; Diaz, H.; Al-Amin, A. Q.; Guerra, J. B. S. O. A.; Hulbert, M.; Farooq, H.; Klavins, M.; Saroar, M.; Lorencova, E. K.; Suresh, J.; Soares, A.; Morgado, F.; O'Hare P.; Wolf, F.; Azeiteiro, M. Climate Change Policies and Agenda: Facing Implementation Challenges and Guiding Responses. Environmental Science and Policy, 104, 190-198, 2020. doi: 10.1016/j. envsci.2019.12.001

Amaru, S.; Chhetri, B. N. Climate Adaptation: Institutional Response to Environmental Constraints, and the Need for Increased Flexibility, Participation, and Integration of Approaches. Applied Geography, 39, 128-139, 2013. Available on: doi: 10.1016/j.apgeog.2012.12.006

Butler, J. R. A.; Suadnya, W.; Puspadi, K.; Sutaryono, Y.; Wise, R. M.; Skewes, T. D.; Kirono, T. D.; Bohenky, E. L.; Handayani, T.; Habibi, P.; Kisma, M.; Suharto, I.; Hanartani, S.; Supartarningsih, S.; Ripaldi, A.; Fachury, A.; Yanuartati, Y.; Abbas, G.; Ash, A. Framing the Application of Adaptation Pathways for Rural Livelihoods and Global Changes in Eastern Indonesian Islands. Global Environmental Change, 8, 368-382, 2014. doi: 10.1016/j.gloenvcha.2013.12.004

CSNA - National Council of Food and Nutritional Security. Characterization of the Brazilian Semi-Arid Lands. Presidency of the Republic of Brazil, 2014. Available on: <http:// www4.planalto.gov.br/consea/comunicacao/artigos/2014/ caracterizacao-do-semiarido-brasileiro-1>. Access on: Feb. 8, 2020.
Davis, R.; Campbell, R.; Hildon, Z.; Hobbs, L.; Michie, $\mathrm{S}$. Theories of Behaviour and Behaviour Change Across the Social and Behavioural Sciences: A Scoping Review. Health Psychology Review, 9(3), 323-344, 2015. doi: 10.1080/17437199.2014.941722

De Souza, K.; Kituyi, E.; Harvey, B.; Leone, M.; Murali, K. S.; Ford, J. D. Vulnerability to Climate Change in Three Hot Spots in Africa And Asia: Key Issues for Policy-Relevant Adaptation and Resilience-Building Research. Regional Environmental Change, 15, 747-753, 2015. doi: 10.1007/ s10113-015-0755-8

Di Gregorio, M.; Fatorelli, L.; Paavola, J.; Locatelli, B.; Pramova, E.; Nurrochmat, D. R.; May, P. H.; Brockhaus, M.; Sari, I. M.; Kusumadewi, S. D. Multilevel Governance and Power in Climate Change Policy Networks. Global Environmental Change, 54, 64-77, 2019. doi: 10.1016/j. gloenvcha.2018.10.003

Dixon, J. L.; Stringer, L. C.; Challinor, A. J. Farming System Evolution and Adaptive Capacity: Insights for Adaptation Support. Resources, 3, 182-214, 2014. doi: 10.3390/resources3010182

England, M. I.; Dougil, A. J.; Stringer, L. C.; Vincent, K. E.; Pardoe, J.; Kalaba, F. K.; Mkwambisi, D. D.; Namaganda, E.; Afionis, S. Climate Change Adaptation and Cross-Sectoral Policy Coherence in Southern Africa. Regional Environmental Change, 18, 2059-2071, 2018. doi: 10.1007/ s10113-018-1283-0

EU - European Union. SWOT (Strengths, Weakness, Opportunities, Threats). Evaluation Methodological Approach. Capacity4DEV. 2020. Available on: <https://europa.eu/ capacity4dev/evaluation_guidelines/wiki/swot-streng- 
hts-weakness-opportunities-threats- $0>$. Access on: Aug. 06, 2020 .

Fankhauser, S. Adaptation to Climate Change. Annual Review of Resource Economics, 9(1), 209-230, 2017. doi: 10.1146/annurev-resource-100516-033554

Ferreira Costa, C. G.; Holanda, A. K. C.; Díaz-Ambrona, C. G. H. Riesgo, Innovación, y Desarrollo en un Clima Cambiante: El Papel de las Políticas de Preparación para Sequías y la Gestión de Riesgo de Desastres en Ceará, Brasil. Journal of Environmental Management and Sustainability (JEMS), 5(3), 87-105, 2016. doi: 10.5585/geas.v5i3.505

Ford, J. D.; Berrang-Ford, L.; Bunce, A.; McKay, C.; Irwin, M.; Pearce, T. The Status of Climate Change Adaptation in Africa and Asia. Regional Environmental Change 15(5), 801-814, 2015. doi: 10.1007/s10113-014-0648-2

Gannon, K. E.; Crick, F.; Atela, J.; Babagaliyeva, Z.; Batool, S.; Bedelian, C.; Carabone, E.; Conway, D.; Diop, M.; Fankhauser, S.; Jobbins, G.; Ludi, E.; Qaisrani, A.; Rouhaud, E.; Simonet, C.; Suleri, A.; Wade, C. T. Private Adaptation in Semi-Arid Lands: A Tailored Approach to 'Leave No One Behind.' Global Sustainability, 3(6), 1-12, 2020. doi: 10.1017/sus.2019.26

Hatfield, J. L.; Sivakumar, V. K.; Prueger, J. H. Climate Extremes, and Impacts on Agriculture. Agroclimatology: Linking Agriculture to Climate. American Society of Agronomy, 60(23), 2018. Available on: doi: 10.2134/agronmonogr60.2016.0003

Hogarth, J. R.; Wójcik, D. An Evolutionary Approach to Adaptive Capacity Assessment: A Case Study of Soufrière, Saint Lucia. Sustainability, 8(3), 228, 2016. doi: 10.3390/ su8030228

Huang, J.; Ji, M.; Xie, Y.; Wang, S.; He, Y.; Ran, J. Global Semi-Arid Climate Change Over the Last 60 Years. Climate Dynamics, 46, 1131-1150, 2015. doi: 10.1007/s00382-0152636-8

IBGE - Brazilian Institute of Geography and Statistics. Brazilian Semi-Arid Region. 2017. Available on: <https://www. ibge.gov.br/en/geosciences/maps/regional-maps/19380-brazilian-semi-arid.html? $=\& \mathrm{t}=\mathrm{o}-q u e-\mathrm{e}>$. Access on: Apr. 27, 2020 .
IBGE - Brazilian Institute of Geography and Statistics. Estimates of Resident Population in Brazilian Municipalities. Date of Reference on July 1, 2019.

IICA - Inter-American Institute for Cooperation on Agriculture. Análise do Arcabouço Institucional Existente para a Gestão de Riscos de Desastres no Estado do Ceará e Brasil. Plano Integrado de Gestão de Riscos de Desastres do Estado do Ceará (PIGRD-CE). Author: Ferreira Costa, C. G. Projeto de Desenvolvimento Rural Sustentável -PDRS/ Projeto São José III. SDA-CE/ IICA. Brasília, 2015. Available on: $<$ http://opackoha.iica.int/cgi-bin/koha/opac-detail. pl?biblionumber $=36221>$. Access on: 18 Apr. 2020.

IPCC - Intergovernmental Panel on Climate Change. Climate Change 2007: Impacts, adaptation, and vulnerability. Contribution of Working Group II to the Fourth Assessment Report of the Intergovernmental Panel on Climate Change. Cambridge University Press, Cambridge, UK, 2007. p. 745777. Available on: <https://www.ipcc.ch/report/ar4/wg2/ inter-relationships-between-adaptation-and-mitigation/>. Access on: Aug. 08, 2020.

IPCC - Intergovernmental Panel on Climate Change. Climate Change 2014: Impacts, Adaptation, and Vulnerability. Part A: Global and Sectoral Aspects. Contribution of Working Group II to the Fifth Assessment Report of the Intergovernmental Panel on Climate Change. Cambridge University Press, 2014.

IPECE - Ceará's Economic Research and Strategy Institute. Regions of Territorial Planning of the State of Ceará. Government of Ceará, 2020. Available on: <https://www. ipece.ce.gov.br/regioes-de-planejamento/>. Access on: Aug. 08, 2020.

Kane, R. Periodicities, ENSO Effects and Trends of Some South African Rainfall Series - An Update. South African Journal of Science, 105, 109-207, 2009. Available on: $<$ http://www.scielo.org.za/pdf/sajs/v105n5-6/a1210556. pdf $>$. Access on: Apr. 10, 2020.

Marengo, J. A.; Lincoln, M. A.; Alvala, R. C. S.; Cunha, A. P.; Brito, S.; Moraes, O. L. L. Climatic Characteristics of the 2010-2016 Drought in the Semiarid Northeast Brazil Region. Annals of the Brazilian Academy of Sciences, 90(2), 2018. doi: 10.1590/0001-3765201720170206 
MDR - Ministry of Regional Development. Brazilian Atlas of Natural Disasters containing 27 volumes (Ceará Chapter, and Brazil), with records from 1991 to 2012. Integrated Disaster Information System (S2iD). MDR, 2012. Available on: <https://s2id.mi.gov.br/paginas/atlas/>. Access on: Feb. 1, 2020.

MDR - Ministry of Regional Development. National Policy for Civil Defense and Protection (PNPDEC). Instituted by Law No. 12.608 of April 10, 2012, published in the Federal Official Gazette No. 70, of April 11, 2012, brings the principles, objectives, and instruments of how management disaster risk management and disaster management will be implemented in Brazil. 2012a. Available on: $<$ https:// www.mdr.gov.br/protecao-e-defesa-civil/politica-nacional-de-protecao-e-defesa-civil>. Access on: Apr. 27, 2020.

Mensah, J. Sustainable Development: Meaning, History, Principles, Pillars, and Implications for Human Action: Literature Review. Cogent Social Sciences, 5(1), 21, 2019. Available on: $<$ https://www.tandfonline.com/doi/full/10.1 080/23311886.2019.1653531>. Access on Aug. 08, 2020.

Mubaya, C. P.; Mafongoya, P. The Role of Institutions in Managing Local-Level Climate Change Adaptation in Semi-Arid Zimbabwe. Climate Risk Management, 16, 93105, 2017. doi: 10.1016/j.crm.2017.03.003

Ngonyani, H.; Mourad, K. A. Role of Water User Associations on the Restoration of the Ecosystem in Tanzania. Water, 11(1), 141, 2019. doi: 10.3390/w11010141

Ojwang, L.; Rozendo, S.; Celliers, L.; Obura, D.; Muiti, A.; Kamula, J.; Mwangi, M. Assessment of Coastal Governance for Climate Change Adaptation in Kenya. Earth's Future, 5(11), 1119-1132, 2017. doi: 10.1002/2017EF000595

Pereira, M. P. S.; Mendes, K. R.; Justino, F.; Couto, F.; Silva, A. S.; Silva, D. F.; Malhado, A. C. M. Brazilian Dry Forest (Caatinga) Response to Multiple ENSO: The Role of Atlantic and the Pacific Ocean. Science of the Total Environment, 705, 25p, Feb. 2020, 135717, 2020. doi: 10.1016/j. scitotenv.2019.135717

Rajaud, A.; Noblet-Ducoudré, N. Tropical Semi-Arid Regions Expanding Over Temperate Latitudes Under Climate Change. Climatic Change, 144, 703-719, 2017. doi: 10.1007/s10584-017-2052-7
Ranabhat, S.; Ghate, R.; Bhatta, L. D.; Agrawal, N. K.; Tanhkha, S. Policy Coherence and interplay between climate change adaptation policies and the forest sector in Nepal. Environmental Management, 61, 968-980, 2018. doi: $10.1007 / \mathrm{s} 00267-018-1027-4$

Russel, D.; Beck, S.; Campos, I.; Capriolo, A.; Castellari, S.; Uyl, R. M.; Gebhardt, O.; Hildén, M.; Jensen, A.; Karali, E.; Mäkinen, K.; McGlade, K.; Nielsen, H. Ø.; Penha-Lopes, G.; Rendón, O.; Tröltzsch, J.; Weiland, S. Analyzing the Policy Framework for Climate Change Adaptation. In: Exploring sustainable pathways - from local to wider policies. Adapting to Climate Change in Europe, 2018. p. 273-313. doi: 10.1016/B978-0-12-849887-3.00006-X

Santos, C. A. C.; Mariano, D. A.; Nascimento, F. C. A.; Dantas, F. R. C.; Oliveira, G.; Silva, M. T.; Silva, L. L.; Silva, B. B.; Bezerra, B. G.; Safa, B.; Medeiros, S. S.; Neale, C. M. U. Spatio-Temporal Patterns of Energy Exchange and Evapotranspiration During an Intense Drought for Drylands in Brazil. International Journal of Applied Earth Observation and Geoinformation, 85, 11p., 2020. doi: 10.1016/j. jag.2019.101982

SDA -Secretaria de Desenvolvimento Agrário do Ceará. Plano Integrado de Gestão de Riscos de Desastres do Estado do Ceará (PIGRD-CE). Termo de Referência n 04/2014/ Banco Mundial/IICA através do Projeto de Desenvolvimento Rural Sustentável - PDRS/Projeto São José. SDA-CE/ IICA. Author: Ferreira Costa, C. G Brasília. 2015. doi: 10.13140/RG.2.1.1040.2000

SNZ - Standards New Zealand. Risk Management Standard. AS/NZS ISO 31000:2009. Available on: <https://www. standards.govt.nz/search-and-buy-standards/standards-information/risk-managment/>. Access on: Aug. 08, 2020.

SUDENE - Superintendence of Northeast Development. Maps, Shapefile, and Infographic of the Semiarid Lands of Northeast of Brazil. Ministry of National Integration, 2017. Available on: <http://www.sudene.gov.br/delimitacao-do-semiarido>. Access on: Feb. 18, 2020.

SUDENE -Superintendence of Northeast Development. Resolution No. 107/2017. Establishes Technical and Scientific Criteria for the Delimitation of the Brazilian Semi-Arid Region and Procedures for Revising its Scope. Federal Public Service. Ministry of National Integration. 
SUDENE/Recife. 2p. 2017a. Available on: <http://sudene. gov.br/images/2017/arquivos/Resolucao-107-2017.pdf>. Access on: Feb. 11, 2020.

SUDENE - Superintendence of Northeast Development. Resolution No. 115/2017. Approves Proposition No. 113/2017, which Adds Municipalities to the list Approved by CONDEL Resolution No. 107, and July 27, 2017 b. Federal Public Service. Ministry of National Integration. SUDENE/Recife. 4p. 2017b. Available on: <http://sudene. gov.br/images/arquivos/conselhodeliberativo/resolucoes/ resolucao115-23112017-delimitacaodosemiarido.pdf>. Access on: Feb. 10, 2020.

SUDENE - Superintendence of Northeast Development. Delimitation of the Semiarid Lands (SALs) of the Northeast of Brazil. Ministry of National Integration, 2020. Available on: $<$ http://www.sudene.gov.br/delimitacao-do-semiarido $>$. Access on: Feb. 16, 2020.

Ting, M.; Kushnir, Y.; Seager, R.; Li, C. Forced and Internal Twentieth Century SST Trends in the North Atlantic. American Meteorological Society, 22(6), 1469-1481, 2009. doi: 10.1175/2008JCLI2561.1

Torfing, J.; Peter, B. G.; Pierre, J.; Sørensen, E. Interactive governance: Advancing the paradigm. $O x$ ford Scholarship Online, 2012. doi: 10.1093/acprof:oso/9780199596751.001.0001

Tucker, J.; Daoud, M.; Oates, N.; Few, R.; Conway, D.; Mtisi, S.; Matheson, S. Social Vulnerability in Three High-Poverty Climate Change Hot Spots: What Does the Climate Change Literature Tell Us? Regional Environmental Change, 15, 783-800, 2015. doi: 10.1007/s10113-0140741-6

UNCCD - United Nations Convention to Combat Desertification. Desertification: A Visual Synthesis. Authors: Hori, Y.; Stuhlberger, C.; Simonett, O. PreventionWeb-UNDRR. 52p. 2011. Available on: <https://www.preventionweb.net/ publications/view/29359\#: :text=This $\% 20$ book $\% 20$ is $\% 20$ intended $\% 20$ to, $\mathrm{a} \% 20$ comprehensive $\% 20$ set $\% 20$ of $\% 20$ graphics>. Access on: Aug. 08, 2020.

UNCCD - United Nations Convention to Combat Desertification. Annex III: Latin America and the Caribbean (LAC). The Regions. The Convention. UNCDD. 2020.
Available on: $<$ https://www.unccd.int/convention/regions/ annex-iii-latin-america-and-caribbean-lac $>$. Access on: Aug. 08, 2020.

UNDP - United Nations Development Programme. Adaptation Policy Frameworks for Climate Change: Developing Strategies, Policies, and Measures. Lim, B.; Spanger-Siegried, E.; Burton, I.; Malone, E. L.; Huq, S. Cambridge University Press, 2004. Available on: $<$ https:// www.preventionweb.net/files/7995_APF.pdf $>$. Access on: Aug. 08, 2020.

UNISDR - United Nations International Strategy for Disaster Reduction. Sendai Framework for Disaster Risk Reduction, 2015-2030. United Nations International Strategy for Disaster Reduction. 37p. 2015. Available on: <https:// www.undrr.org/>. Access on: Jan. 2, 2020.

UNDRR - United Nations Office for Disaster Risk Reduction. UNDRR Tools. 2020. Available on: $<$ https://www. undrr.org/>. Access on: Jan. 2, 2020.

WB - World Bank. Institutional Perception Mapping. Analysis of Social and Poverty Impacts. Poverty Analysis Monitoring Team, DFID, and Social Development Department, World Bank. 2008. Available on: $<$ https://www.worldbank. org/en/webarchives/archive?url=httpzzxxweb.worldbank. org/archive/website01031/WEB/0_C-184.HTM $>$. Access on: Jan. 10, 2020.

WB - World Bank. Climate Change Governance. Policy Research Working Paper 4941 - Background Paper of the 2010 World Development Report. Meadowcroft, J., 2009. Available on: <http://documents.worldbank.org/curated/ en/210731468332049368/Climate-change-governance>. Access on: Aug. 08, 2020.

WB - World Bank. Ceará Rural Sustainable Development and Competitiveness Project Phase III (P167455). Agriculture Global Practice/Water Global Practice/Latin America and Caribbean Region (LAC). Technical Report No. PAD3167. 92 p. 2019. Available on: <http://documents1.worldbank.org/curated/pt/489161563760847949/ pdf/Brazil-Second-Phase-of-Ceara-Rural-Sustainable-Development-and-Competitiveness-Project.pdf $>$. Access on: Aug. 07, 2020. 
Williams, D. S.; Rosend, S.; Sadasing, O.; Celliers, L. Identifying Local Governance Capacity Needs for Implementing Climate Change Adaptation in Mauritius. Climate Policy, 20(5), 548-562, 2020. doi: 10.1080/14693062.2020.1745743

Wisner, B.; Brenes, A.; Marchezini, V. Non-Governmental Organizations and Natural Hazard Governance in Latin America and the Caribbean. Oxford Research Encyclopedia of Natural Hazard. Natural Hazard Science, 2020. doi: 10.1093/acrefore/9780199389407.001.0001/acrefore-9780199389407-e-333
WMO/WGP - World Meteorological Organization/Global Partnership. Benefits of Action and Costs of Inaction: Drought Mitigation and Preparedness - Literature Review. Gerber, N.; Mirzabaev, A. Integrated Drought Management Programme (IDMP). Working Paper 1. WMO. Geneva, Switzerland, and GWP, Stockholm, Sweden. 24p. 2017. Available on: $<$ https://library.wmo.int/doc_num.php?explnum_id=3401>. Access on: Jan. 18, 2020.

Yomo, M.; Villamor, G. B.; Aziadekey, M.; Olorunfemi, F.; Mourad, K. A. Climate change adaptation in Semi-Arid Ecosystems: A Case Study from Ghana. Climate Risk Management, 27, 2020. doi: 10.1016/j.crm.2019.100206 